\title{
PERENCANAAN PERBAIKAN PROSES PADA PRODUKSI GENTENG DENGAN METODE SIX SIGMA
}

\author{
DWI IRYANING HANDAYANI \\ Jurusan Teknik Industri Universitas Muhammadiyah Malang \\ Jalan Raya Tlogomas 248 Malang \\ E-mail: dwiiryaning@yahoo.com
}

\begin{abstract}
UD. BJ Mendit on Mendit Barat, Kec. Pakis is one of centrale of home industry in Malang with it's roof production process. From the observation that the researcher do into UD. BJ Mendit, finded that the production process had been doing often with technical and non technical problems that make some failed roof product with the criterion are keropos, break, barst, gopel, sandbank. Way of this roof production planning repair is important to do so that can make this production unit produce an unfailed product and reduce loss. Purposes of this research are identifying types of roof failed product, analysing main cause of roof failed product with FMEA, and giving recommended action for Mendit's roof production process repair. This research doing the same steps as same as Six Sigma cycle: DMAIC, but not doing the last step, Control. On Define step, are doing product identifying and make the Six Sigma team. On Measure step, are determining priority failed product identifying into CTQ (Critical To Quality) and measurement of present performance with counting the DPMO (Defect Per Million Opportunities) dan Sigma level. On Analyze step, is detecting main atributs that influencing the failed product on CTQ. On Improve step, is doing process improvement with developing alternative to reduce failed product atributs. From the steps had done, finded that the biggest failed criterion is keropos. Keropos is caused by lack of skill and correctness of worker on processing the raw material, can also caused by process execution which not fully corret so that produce critical process to be repaired first to increase the quality of Mendit's roof.
\end{abstract}

Key words: roof, production process, six sigma, DMAIC

\section{PENDAHULUAN}

UD BJ Mendit di Mendit Barat, Kec. Pakis adalah salah satu pusat home industry yang terkenal di daerah Malang dengan produksi gentengnya. Produk-produk yang dihasilkan unit usaha ini ada 5 jenis produk antara lain genteng karang pilang, wuwung, genteng plisir, genteng layur kecil dan genteng layur besar. Seiring dengan gulung tikarnya beberapa unit usaha sejenis di Mendit, dengan pesatnya pengembangan pemukiman di Malang turut membuat permintaan genteng menjadi meningkat.

Namun dapat dilihat persaingan produk genteng khususnya genteng tanah liat dari Mendit semakin ketat dengan munculnya produk-produk genteng tanah liat dari Trenggalek dan produksi genteng dari perusahaan pembuat genteng yang menggunakan teknologi yang lebih modern. Oleh karena itu, upaya perbaikan proses produksi genteng ini sangat penting untuk dilaksanakan sehingga unit usaha ini mampu menghasilkan produk bebas cacat dan mengurangi kerugian yang timbul karena cacat produk.

Berdasarkan pengamatan yang dilakukan peneliti pada UD BJ Mendit, ternyata proses produksi yang dilaksanakan saat ini masih sering ditemukan masalah-masalah teknis dan non teknis yang menyebabkan produk gentengyang dihasilkan menjadi cacat antara lain keropos, pecah, retak, gopel dan gosong. Dengan adanya cacat-cacat tersebut akan menyebabkan pengerjaan ulang atau bahkan terjadi diskon harga untuk produk cacat yang mengakibatkan keuntungan yang diperoleh semakin kecil.

Tujuan penelitian ini adalah menganalisis penyebab utama cacat pada genteng menggunakan FMEA. memberikan recommended action untuk perbaikan proses produksi pada genteng Wendit.

\section{METODE}

Tahap identifikasi dan penelitian awal. Merupakan tahap penelitian awal untuk melakukan 
penelitian. Pelaksanaan survei lapangan dimaksudkan untuk mengetahui kondisi riil dari unit usaha pada saat ini, terutama yang berkaitan dengan objek yang akan diteliti. Pelaksanaan survei dilakukan dengan mengamati proses produksi untuk memberikan gambaran dan pemahaman secara garis besar mengenai bagaimana unit usaha yang diteliti dapat menangani terjadinya cacat pada poses produksi.

Data-data yang diperlukan terbagi atas data kualitatif dan data kuantitatif. Data-data kualitatif dapat diperoleh melalui kuesioner, wawancara, dan brainstorming dengan pihak-pihak yang terkait dalam unit usaha, serta informasi-informasi lainnya yang mendukung sistem produksi. Datadata kuantitatif yang diperlukan berupa konsepkonsep yang digunakan dalam penelitian ini adalah konsep tentang Kapabilitas Proses dalam Six Sigma, DPMO (Defect Per Million Opportunities), FMEA (Failure Mode and Effect Analysis) dan RCA (Root Cause Analysis). Data historis, digunakan untuk penghitungan kapabilitas proses dan level sigma unit usaha saat ini.

Proses pengolahan data sesuai dengan metode six sigma dan kondisi riil di unt usaha yang diteliti. Tahap ini terdiri atas: (1) Define pada tahap ini dibentuk tim six sigma dan dilakukan pendefinisian produk dan/atau proses yang akan diperbaiki. Ditetapkan prioritas utama tentang masalah mana yang akan ditangani terlebih dahulu. Tools yang digunakan adalah diagram Pareto. (2) Measure; Adapun hal-hal yang dilakukan pada tahap measure ini meliputi: Menetapkan karateristik kualitas kunci (CTQ) cacat yang berpengaruh dan Menghitung nilai DPMO dan Level Sigma.

Setelah dilakukan proses identifikasi pada tahap measure maka pada tahap ini dapat dilakukan analisis dan diberikan suatu usulan perbaikan bagi perusahaan.

Analyze. Adapun hal-hal yang dilakukan pada tahap analyze ini meliputi: (1) Analisis nilai DPMO dan Sigma level saat ini, dilakukan sebagai acuan/dasar untuk melakukan perbaikan dan peningkatan kinerja atau performasi sistem periode mendatang. (2) Identifikasi faktor-faktor penyebab terjadinya cacat dengan Fish Bone Diagram. (3) Pengidentifikasian potensi kegagalan yang ditimbulkan pada operasi. (4) Penganalisisan RPN tertinggi yang ada pada FMEA sehingga perlu di improve dengan melihat nilai RPN yang tertinggi dengan menggunakan FMEA.

Improve. Pada tahap ini, diberikan usulan perbaikan terhadap proses produksi yang mengacu pada hasil RPN tertinggi dari FMEA pada tahap analyze dan diharapkan mampu mengurangi cacat yang terjadi di unit usaha yang diteliti.

\section{HASIL DAN PEMBAHASAN}

Dalam tahapiniakan dilakukananalisisterhadap faktor-faktor penyebab cacat dengan menggunakan Tool Fish Bone Diagram serta mengidentifikasi mekanisme teknis dalam proses produksi genteng yang menyebabkan terjadinya cacat. Identifikasi tersebut kemudian mengimplementasikan Tool Quality Improvement yang disebut Failure Mode and Effect Analysis (FMEA).

Dengan menggunakan FishBone Diagram atau diagram sebab akibat akan dilakukan analisis faktor-faktor yang menjadi penyebab munculnya cacat pada cacat-cacat utama (CTQ). Diagram sebab akibat disusun dan dibentuk melalui pengamatan dan diskusi di antara tim Six Sigma. Faktor-faktor penyebab munculnya cacat akan dianalisis dari lima faktor, yaitu: manusia, bahan, sistem/metode, peralatan.

Jenis cacat yang akan dianalisis sesuai dengan CTQ adalah keropos.

Cacat keropos pada genteng merupakan jenis cacat yang tidak dapat diidentifikasi secara visual atau kasat mata saat genteng utuh. Jenis cacat keropos ini sering diketahui setelah tahap pembakaran dan terdapat genteng yang pecah atau gopel. Dari pecahan itulah dapat dilihat banyaknya rongga-rongga udara mikro yang terbentuk dalam genteng. Cacat keropos ini sering disebabkan karena seorang pengrajin yang ceroboh dan kurang teliti dalam menakar komposisi adonan, dapat pula karena campuran yang kurang merata sehingga adonan genteng tidak padat. Dapat pula saat pencetakan pengrajin kurang menekan alat saat mencetak. Atau bahkan penggilingan adonan yang kurang merata dan halus. Bahan baku juga dapat mempengaruhi kemunculan cacat ini, seperti tanah liat yang tercampur atau pasir yang kurang halus pengayakannya. Demikian juga dengan alat cetakan genteng yang sudah rusak atau sudah aus sehingga hasil pencetakan tidak sempurna. 
Mode-mode kegagalan yang menyebabkan munculnya cacat diidentifikasi dengan menggunakan failure mode and effect analysis (FMEA). Identifikasi yang dilakukan menggunakan FMEA proses, sehingga dapat mengidentifikasi cacat produk dimulai dari proses yang pertama sampai menjadi sebuah produk. Pembentukan potensial/mekanisme kegagalan, dan metode pengendalian proses yang ada saat ini dilakukan dengan diskusi di antara anggota tim Six Sigma dan dipandu oleh hasil dari diagram FishBone. Faktorfaktor penyebab yang tercantum pada diagram $F$ ish Bone/sebab akibat bisa menjadi mode kegagalan atau mekanisme kegagalan pada tabel FMEA. Langkah selanjutnya adalah memberikan penilaian secara kuantitatif terhadap seberapa besar efek yang ditimbulkan dari penyebab kegagalan/cacat (severity), seberapa sering penyebab kegagalan tersebut berlangsung dalam proses (occurance) dan seberapa baik metode pengendalian proses yang ada saat ini (detection).

Demikian pula tindakan perbaikan/ recommended action yang dirumuskan untuk menekan ranking severity dan occurance adalah hasil diskusi tim Six Sigma.

Setelah sumber-sumber dan penyebab dari masalah kualitas teridentifikasi, maka perlu dilakukan penetapan rencana tindakan. Pengembangan rencana tindakan merupakan salah satu aktivitas yang penting dalam program peningkatan kualitas, pada tahap ini digunakan analisis 5W-H untuk membantu menetapkan pengembangan rencana tindakan perbaikan proses produksi untuk peningkatan kualitas Six Sigma di genteng mendit.

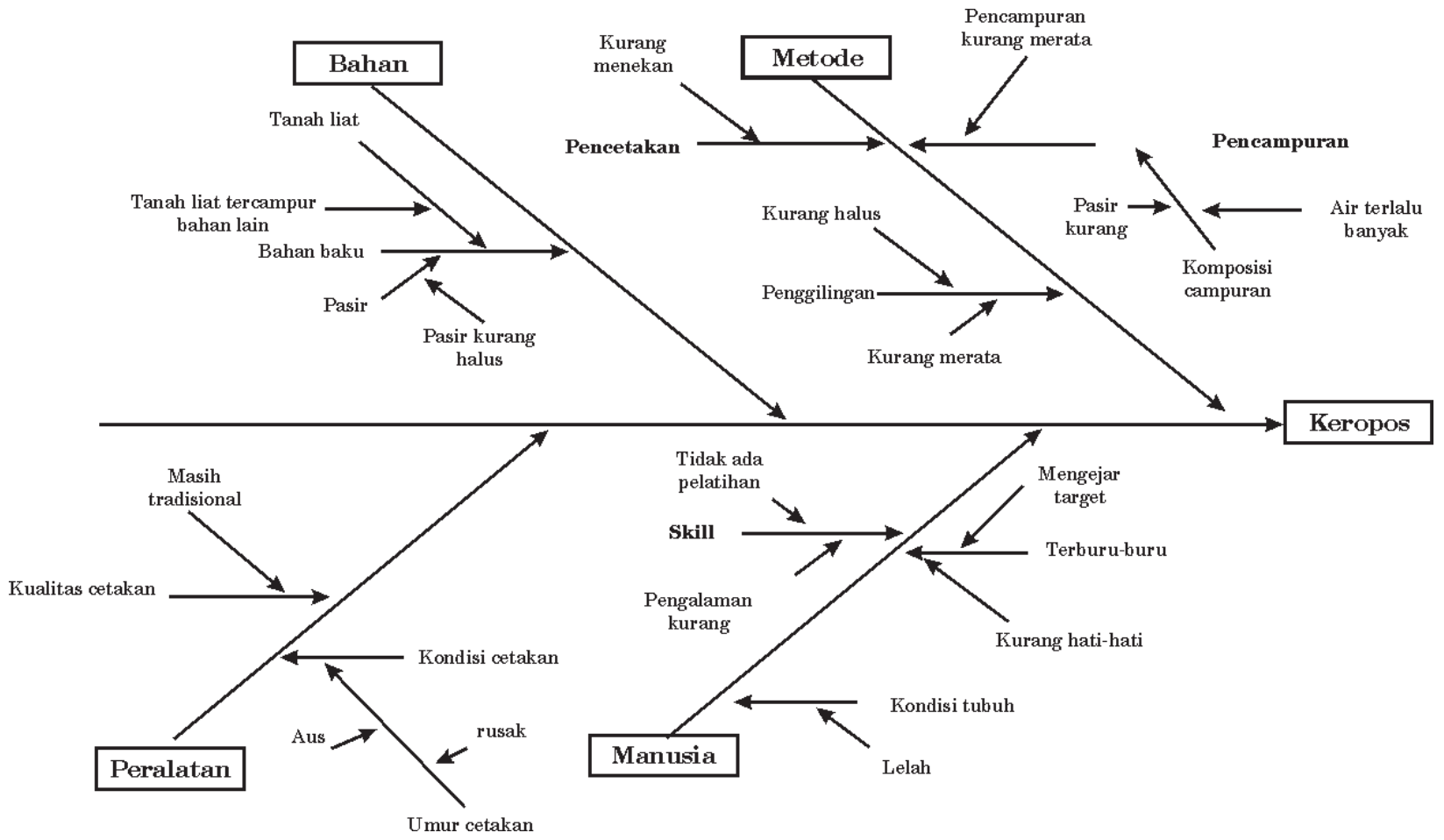

Gambar 1. Fishbone cacat keropos 


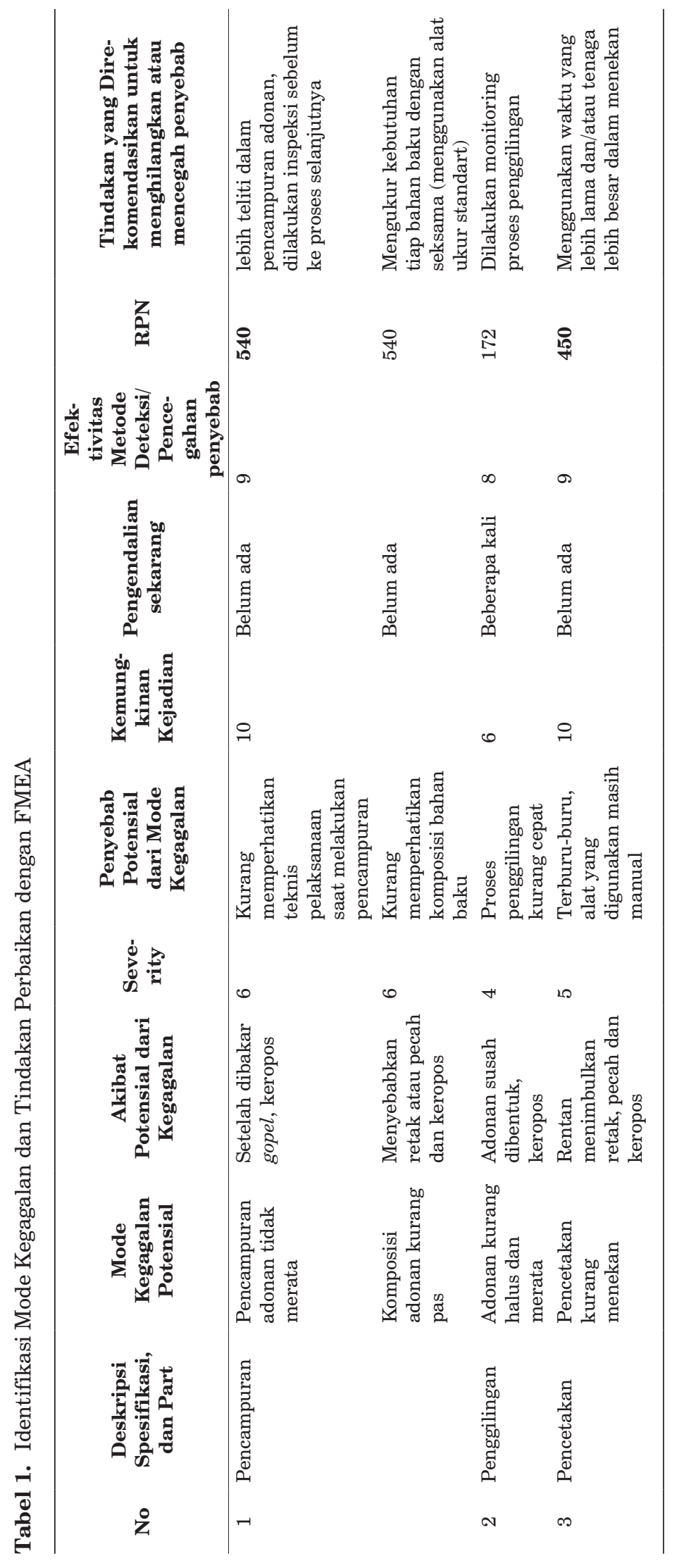


Tabel 2. Penggunaan Metode 5W-H Berdasarkan RPN Tertinggi

\begin{tabular}{|c|c|c|c|}
\hline Jenis & $5 \mathrm{~W}-\mathrm{H}$ & Deskripsi & Tindakan \\
\hline Tujuan Utama & What (apa?) & $\begin{array}{l}\text { Apa yang menjadi target utama } \\
\text { dari perbaikan proses prduksi } \\
\text { genteng Mendit? }\end{array}$ & \multirow{2}{*}{$\begin{array}{l}\text { Target dari perbaikan adalah mendefinisikan cacat } \\
\text { kemudian mengetahui penyebab cacat. Dari lima } \\
\text { jenis cacat yang ada yakni gopel, retak, pecah, } \\
\text { gosong dan keropos, keropos merupakan cacat } \\
\text { dengan jumlah yang sangat besar. } \\
\text { Tindakan yang direncanakan untuk dilakukan } \\
\text { adalah mengundang ahli/profesional dalam bidang } \\
\text { proses produksi genteng untuk memberikan arahan } \\
\text { kepada pengrajin mengenai cara proses produksi } \\
\text { genteng yang benar. Rencana tindakan perbaikan } \\
\text { diperlukan untuk mengetahui dari proses mana } \\
\text { penyebab cacat terbesar berasal, sehingga dapat } \\
\text { diperbaiki terlebih dahulu. Dalam hal ini, proses } \\
\text { penyebab cacat terbesar adalah proses pencampuran } \\
\text { dan pencetakan (dilihat dari nilai RPN) }\end{array}$} \\
\hline $\begin{array}{l}\text { Alasan } \\
\text { Kegunaan }\end{array}$ & $\begin{array}{l}\text { Why } \\
\text { (mengapa?) }\end{array}$ & $\begin{array}{l}\text { Mengapa rencana tindakan itu } \\
\text { diperlukan? }\end{array}$ & \\
\hline Lokasi & $\begin{array}{l}\text { Where } \\
\text { (di mana?) }\end{array}$ & $\begin{array}{l}\text { Dimana rencana tindakan } \\
\text { tersebut akan dilakukan? } \\
\text { apakah harus? }\end{array}$ & \multirow{3}{*}{$\begin{array}{l}\text { Rencana tindakan dilakukan pada proses yang } \\
\text { paling kritis untuk diperbaiki karena merupakan } \\
\text { penyebab cacat terbesar. Dalam penelitian ini } \\
\text { berada pada proses pencampuran dan pencetakan. } \\
\text { Pada proses pencampuran, pengrajin diharapkan } \\
\text { mampu mengukur kebutuhan bahan baku secara } \\
\text { tepat, lebih teliti dan melakukan inspeksi sebelum } \\
\text { dan sesudah proses pencampuran tersebut } \\
\text { dilakukan. Sedangkan pada proses pencetakan, } \\
\text { pengrajin diharapkan tidak terburu-buru dalam } \\
\text { menekan; menggunakan waktu yang lebih lama } \\
\text { atau tenaga yang lebih besar untuk dapat mencetak } \\
\text { genteng secara lebih baik. Rencana tersebut harus } \\
\text { secepatnya ditindaklanjuti untuk memperbaiki } \\
\text { kualitas genteng. } \\
\text { Pelaksana rencana tindakan adalah pengrajin } \\
\text { genteng dengan arahan profesional dan kontrol } \\
\text { pemilik. Pengrajin yang harus melakukan rencana } \\
\text { tersebut, bukan orang lain, orang lain hanya } \\
\text { membimbing, karena saat orang lain itu selesai } \\
\text { memberi contoh, pengrajin akan melakukan hal } \\
\text { yang sama seperti sebelumnya. Proses perbaikan } \\
\text { akan gagal. }\end{array}$} \\
\hline $\begin{array}{l}\text { Sekuens } \\
\text { (urutan) }\end{array}$ & When (kapan?) & $\begin{array}{l}\text { Kapan aktivitas tersebut terbaik } \\
\text { dilakukan? } \\
\text { apakah dapat dikerjakan } \\
\text { kemudian? }\end{array}$ & \\
\hline Orang & Who (siapa?) & $\begin{array}{l}\text { Siapa yang mengerjakan rencana } \\
\text { tindakan? apakah ada orang lain } \\
\text { yang bisa mengerjakan aktivitas } \\
\text { itu? mengapa harus orang itu? }\end{array}$ & \\
\hline Metode & $\begin{array}{l}\text { How } \\
\text { (bagaimana?) }\end{array}$ & $\begin{array}{l}\text { Bagaimana mengerjakan aktivitas } \\
\text { rencana tindakan tersebut? } \\
\text { Apakah metode yang dipakai } \\
\text { adalah metode terbaik? Apa ada } \\
\text { cara lain yang lebih mudah? }\end{array}$ & $\begin{array}{l}\text { Pemilik mengkoordinir pengrajin pada suatu waktu } \\
\text { untuk bertemu dan menerima bimbingan/pelatihan } \\
\text { dari pakar genteng. Pertemuan tersebut berguna } \\
\text { untuk menambah wawasan dan pengetahuan } \\
\text { pengrajin mengenai cacat, cara menghindari cacat, } \\
\text { perbaikan proses dan keuntungan lebih saat cacat } \\
\text { tersebut hilang. Pertemuan bertempat di lokasi } \\
\text { produksi genteng, senyampang dengan penjelasan } \\
\text { gamblang, pengrajin diajak untuk mempraktekkan } \\
\text { alternatif cara produksi genteng yang lebih baik. } \\
\text { Dengan metode ini diharapkan mudah diterima dan } \\
\text { mudah dilaksanakan karena dilakukan pengrajin } \\
\text { langsung di tempat produksi.Setelah pertemuan } \\
\text { ini berakhir, tetap dilakukan monitoring ekstra } \\
\text { untuk kegiatan produksi setidaknya selama satu } \\
\text { bulan dengan bantuan pemilik agar pengrajin dapat } \\
\text { terbiasa dengan tindakan perbaikan tersebut }\end{array}$ \\
\hline
\end{tabular}




\section{SIMPULAN}

Hasil identifikasi cacat menunjukkan bahwa cacat yang paling berpengaruh dalam proses produksi genteng mendit adalah jenis cacat keropos, penyebab terjadinya jenis cacat tersebut adalah: Keropos disebabkan karena kurangnya keahlian dan ketelitian pengrajin dalam mengolah bahan baku (dilihat dari mode kegagalan pengaturan komposisi adonan dan pencampuran adonan) menjadi genteng yang berkualitas. Dari proses pencampuran, pembentukan hingga penggilingan merupakan proses-proses kritis yang harus dilakukan perbaikan terlebih dahulu untuk dapat meningkatkan kualitas genteng mendit.

Berdasarkan nilai RPN terbesar pada FMEA dan analisis 5W-H, untuk menentukan rencana perbaikan cacat yang sering terjadi adalah: pemilik menyelenggarakan kegiatan pelatihan untuk para pengrajin genteng, dan pemilik lebih meningkatkan pengawasannya kepada para pengrajin genteng.

\section{DAFTAR PUSTAKA}

Astutik, S.R., 2008. Pengurangan Waste dengan Pendekatan Lean Six Sigma pada Proses Produksi Benih Jagung. Malang: Tugas Akhir Jurusan Teknik Industri, Universitas Muhammadiyah Malang.
Baya'sud, F., 2008. Evaluasi dan Perbaikan Proses Produksi dengan pendekatan Lean Six Sigma. Malang: Tugas Akhir Jurusan Teknik Industri, Universitas Muhammadiyah Malang.

Gaspersz, V., 2006. Lean Six Sigma for Manufacturing and Service Industries. Jakarta: PT Gramedia Pustaka Utama.

Gaspersz, V., 2002. Pedoman Implementasi Program Six Sigma Terintegrasi dengan ISO 9001:2000, $M B N Q A$, dan HACCP. Jakarta: PT Gramedia Pustaka Utama.

Hamidi, H., 2008. Perencanaan Peningkatan Kualitas Produk Rokok dengan Pendekatan Six Sigma. Malang: Tugas Akhir Jurusan Teknik Industri, Universitas Muhammadiyah Malang.

Kusuma, Y., 2007. Integrasi Balanced Scorecard dalam Pengukuran Kinerja Perusahaan dengan Program perbaikan Six Sigma. Malang: Tugas Akhir Jurusan Teknik Industri, Universitas Muhammadiyah Malang.

Pande, P.S., Neuman R.P., dan Roland R.C., 2002. The Six Sigma Way: Team Fieldbook, an Implementation Guide for Process Improvement. McGraw-Hill.

Rahmat, Z., 2007. Penerapan Metode Six Sigma sebagai Metode Peningkatan Kualitas untuk Menurunkan Jumlah Cacat pada Tas Sekolah. Malang: Tugas Akhir Jurusan Teknik Industri, Universitas Muhammadiyah Malang. 